\title{
Economic freedom and bank efficiency: does ownership and origins matter?
}

\begin{abstract}
Purpose: The paper aims to explore the impact of economic freedom on the efficiency of the Malaysian banking sector. Design/methodology/approach: The analysis is confined into two stages. In the first stage, the bias-corrected data envelopment analysis method is used to compute the efficiency of individual banks. Then bootstrap regressions are used to examine the impact of economic freedom on bank efficiency, while controlling for the potential impacts of contextual variables. Findings: It was found that greater freedom to start new businesses tend to impede the efficiency of banks operating in the Malaysian banking sector. The results indicate that restrictions on the activities of which banks could undertake exert negative impact on their efficiency levels. The empirical findings seem to support for official regulation and supervision of banks by setting the limits on activities which banks could undertake. In addition evidence supporting for government interventions in the foreign exchange and money markets was found. Originality/value: The purpose of the present paper is to extend the earlier works on the performance of the banking sector in a developing economy and establish empirical evidence on the impact of economic freedom. Although empirical evidence which examines the performance of banking sectors is abundant in the literature, to the best of our knowledge, virtually nothing has been published to address the impact of economic freedom.
\end{abstract}

Keyword: Malaysia; Banks; Bootstrap DEA; Bootstrap regression; Economic freedom 